\title{
MADRASAH DINIYAH DALAM MULTI PERSPEKTIF
}

\author{
Ismail \\ STAI Nazhatut Thullab Sampang \\ Email: yajlisismail@gmail.com
}

\begin{abstract}
Abstrak:
Penelitian tentang madrasah diniyah telah banyak dilakukan oleh para ahli, namun dari sekian penelitian itu masih parsial, yakni penelitian yang hanya menurut satu perspektif. Oleh karena itu, penelitian ini mencoba melihat madrasah diniyah menurut beberapa perspektif, antara lain: perspektif ideologis filosofis, historis, politik, manajemen, dan metodologis. Penelitian tentang madrasah diniyah multi perspektif ini bertujuan untuk menegaskan bahwa madrasah diniyah sebagai lembaga pendidikan dapat dilihat menurut berbagai perspektif yang sejalan dengan perkembangan dunia ilmu (scientific view). Penelitian ini diperoleh hasil antara lain: (1) penyelenggaraan pendidikan madrasah diniyah sebagai lembaga pendidikan Islam memiliki landasan ideologis filosofis yang bersumber dari al-Qur'an dan Hadits; (2) madrasah diniyah memiliki akar sejarahnya sendiri yang sejalan dengan sejarah Islam dan muslim di Indonesia; (3) madrasah diniyah memiliki posisi strategis secara politik; (4) untuk meningkatkan kualitas, secara manajemen madrasah diniyah perlu mendapatkan perhatian yang serius dari stakeholders pendidikan agar madrasah diniyah semakin fungsional bagi bangsa negara; dan (5) peningkatan sumber daya manusia madrasah diniyah sangat dibutuhkan guna meningkatkan mutu pendidikan madrasah diniyah utamanya dalam pembelajaran sehingga terlaksana pembelajaran yang kontekstual.
\end{abstract}

Kata Kunci: Madrasah Diniyah

\section{Abstract:}

Research on madrasah diniyah has been done by many experts, but the research is still partial, ie research which only according to one perspective. Therefore, this research tries to look at madrasah diniyah according to several perspectives, among others: philosophical, historical, political, management, and methodological perspective. Multi perspective research on madrasah diniyah aims to emphasize that madrasah diniyah as an educational institution can be seen according to various 
perspectives that are in line with the development of science world (scientific view). This study obtained results include: (1) the implementation of madrasah diniyah as an Islamic educational institution has a philosophical ideological foundation derived from the Qur'an and Hadith; (2) madrasah diniyah has its own historical roots in line with the history of Islam and Muslims in Indonesia; (3) madrasah diniyah has a strategic political position; (4) to improve the quality, madrasah diniyah management needs to get serious attention from education stakeholders to make madrasah diniyah more functional for nation state; and (5) the improvement of human resources of madrasah diniyah is needed to improve the quality of madrasah diniyah education especially in learning so that the contextual learning is done.

Keywords: Madrasah Diniyah

\section{Pendahuluan}

Madrasah diniyah menjadi objek kajian penelitian karena madrasah diniyah merupakan lembaga pendidikan Islam di Indonesia. Kajian penelitian tentang madrasah diniyah dapat dilakukan melalui berbagai perspektif ${ }^{1}$, antara lain; ideologis, filosofis, historis, politik, manajemen, hingga sosilogis dan lainnya, masing-masing perspektif tersebut saling berkaitan. Dengan kata lain, bahwa madrasah diniyah dapat dikaji menurut berbagai sudut pandang, dan menurut keahlian yang dimiliki oleh sang peneliti.

Artikel ini mencoba mengkaji madrasah diniyah memlalui berbagai perspektif agar diperoleh pemahaman yang konferhensif tentang madrasah diniyah. Kajian dalam artikel ini tidak mendalam karena bertujuan untuk menegaskan bahwa madrasah diniyah dapat dikaji menurut berbagai perspektif. Adapaun pendalamannya dapat dilakukan kajian lebih lanjut menurut masing-masing perspektif.

Kajian tentang madrasah diniyah multiperspektif dibutuhkan untuk menunjukkan bahwa sebagai lembaga pendidikan Islam, madrasah diniyah tetap menarik perhatian untuk diteliti lebih lanjut. Keberlanjutan penelitian tentang madrasah diniyah sejalan dengan keberlanjutan perkembangan dunia ilmu (sicientific view). Oleh karena itu, artikel ini mencoba untuk menjelaskan bagainbagian pokok tentang madrasah diniyah menurut berbagai perspektif yang memiliki relevansi dengan pengetahuan tentang pendidikan (science of education).

\footnotetext{
${ }^{1}$ Perspektif diartikan sebagai sudut pandang. https://kbbi.web.id/perspektif
} 


\section{Mengenal Madrasah Diniyah}

Pengertian tentang madrasah diniyah dapat kita lihat pada beberapa literatur, antara lain menurut Karel A. Steenbrink, madrasah ini (madrasah diniyah awaliyah, wustho, dan aliyah) dimaksudkan sebagai lembaga yang disediakan bagi anak-anak yang pada waktu pagi pergi ke sekolah umum. ${ }^{2}$ Menurut Departemen Agama RI, madrasah diniyah adalah satu lembaga pendidikan keagamaan pada jalur luar sekolah yang diharapkan mampu secara terus menerus memberikan pendidikan agama Islam kepada anak didik yang tidak terpenuhi pada jalur sekolah yang diberikan melalui sistem klasikal serta menerapkan jenjang pendidikan. ${ }^{3}$

Sejalan dengan munculnya kategorisasi madrasah diniyah antara lain madrasah diniyah takmiliyah, maka Kemenag RI memberikan pengertian bahwa madrasah diniyah takmiliyah merupakan salah satu lembaga pendidikan keagamaan Islam di luar pendidikan formal yang diselenggarakan terstruktur dan berjenjang sebagai pelengkap pelaksanaan pendidikan keagamaan. ${ }^{4}$

Sedangkan menurut Headri Amin, madrasah diniyah adalah madrasah-madrasah yang seluruh mata pelajaranya bermaterikan ilmu-ilmu agama, yaitu fiqih, tafsir, tauhid dan ilmu-ilmu agama lainya. ${ }^{5}$ Memperbanyak ilmu agama merupakan sebagian besar tujuan dari pembelajaran di madrasah diniyah. Merujuk pada hadits: "Barangsiapa yang Allah menginginkan dengannya suatu kebaikan, maka Allah akan memahamkannya di dalam urusan agama". ${ }^{6}$

Pengertian yang hampir sama juga disampaikan oleh M. Ridlwan Nasir dengan merujuk pada SKB tiga Menteri tahun 1975, madrasah diniyah adalah suatu bentuk madrasah (tempat belajar) yang hanya mengajarkan ilmu-ilmu agama. Madrasah ini dimaksudkan sebagai lembaga pendidikan agama yang disediakan

2 Karel A. Steenbrink, Pesantren, Madrasah, Sekolah: Pendidikan Islam dalam Kurun Moderen (Jakarta: LP3ES, 1994), 167.

3 Depertemen Agama RI, Pedoman penyelenggaraan dan Pembinaan Madrasah Diniyah (Jakarta: Depag, 2000), 7.

4 Kementerian Agama RI, Pedoman Penyelenggaraan Madrasah Diniyah Takmiliyah (Surabaya: Kanwil Kemenag Jawa Timur, 2015), 7.

5 Headri Amin, Peningkatan Mutu Terpadu Pesantren dan Madrasah Diniyah (Jakarta: Diva Pustaka, 2004), 39.

${ }^{6}$ Abỉ Abd al-Mu'tī Muhammad bin Umar bin Ali Nawāwỉ al-Jāwỉ al-Bantanỉ alTaawwudi, Nihāyat al-Zayn fi Irsyād al-Mubtadiinn (Surabaya: al-Hidayah, tt), 3. 
bagi siswa yang belajar di sekolah umum. ${ }^{7}$ Sedangkan dalam Permenag No 13 Tahun 2014, diniyah takmiliyah yang selanjutnya disebut madrasah diniyah takmiliyah adalah lembaga pendidikan keagamaan Islam pada jalur pendidikan nonformal yang diselenggarakan secara terstruktur dan berjenjang sebagai pelengkap pelaksanaan pendidikan agama Islam pada jenjang pendidikan dasar, menengah dan tinggi. ${ }^{8}$

Dari beberapa pengertian di atas dan oleh karena konteks pembahasan dari kajian teori ini adalah tentang madrasah diniyah takmiliyah, maka dapat disimpulkan bahwa madrasah diniyah takmiliyah adalah lembaga pendidikan nonformal yang khusus mengajarkan ilmu agama Islam untuk melengkapi, memperkaya dan memperdalam pendidikan agama Islam peserta didik menurut jenjangnya dalam rangka peningkatan keimanan dan ketaqwaan kepada Allah SWT.

\section{Perspektif Ideologis Filosofis}

Praktik penyelenggaraan pendidikan bagi umat Islam bukanlah sesuatu yang baru, sebab sejak masa Nabi Muhammad SAW masih hidup telah berlangsung penyelenggaraan pendidikan di dalam Islam. Gairah umat Islam untuk mengembangkan ilmu pengetahuan - baik ilmu yang langsung berhubungan dengan tugas pokok manusia yang digariskan oleh Allah SWT, yaitu beribadah kepada-Nya ${ }^{9}$ - maupun tidak. Sehingga merujuk pada pemikiran tersebut, kita mengetahui bahwa praktik pendidikan di dalam Islam tidak pernah terpisahkan dari Islam itu sendiri sebagai agama bagi umat Islam. Oleh karena itu, M.M. Sharif mengatakan bahwa di masa keemasan Islam (abad ke VII - abad ke XVI) umat Islam meraih kejayaannya tidak hanya dalam bidang penyebaran

\footnotetext{
${ }^{7}$ M. Ridlwan Nasir, Mencari Tipologi Format Pendidikan Ideal Pondol Pesantren di Tengah Arus Perubahan (Yogyakarta: Pustaka Pelajar, 2010), 95.

8 Peraturan Menteri Agama No. 13 Tahun 2014 tentang Pendidikan Keagamaan Islam, pasal 1. Dalam Peraturan ini dijelaskan pula bahwa pendidikan diniyah terdiri dari pendidikan diniyah formal, nonformal, dan informal. Pendidikan diniyah formal memiliki jenjang dasar, menengah, dan tinggi (pasal 23 (1)). Pendidikan diniyah formal jenjang pendidikan dasar terdiri dari pendidikan diniyah formal ula dan wustha (pasal 23 (2)). Pendidikan diniyah formal jenjang pendidikan menengah berbentuk pendidikan diniyah formal ulya (pasal 23 (3)). Pendidikan diniyah formal jenjang pendidikan tinggi berbentuk ma'häd ali (pasal 23 (4)). Pendidikan diniyah nonformal berbentuk: madrasah diniyah takmiliyah, pendidikan al-Qur'an, majlis taklim atau pendidikan keagamaan Islam lainnya (pasal 45 (1)). Madrasah diniyah takmiliyah terdiri atas jenjang ula, wustha, ulya, dan al-jami'ah (pasal 46 (3).

${ }_{9}$ QS. Adz-Dzariyat (51: 56): "dan tidak aku ciptakan jin dan manusia kecuali untuk menyembah-Ku".
} 
agama dan perluasan wilayah semata, tetapi juga umat Islam menjadi pencerah ilmu pengetahuan bagi seluruh belahan dunia. Hal ini menurutnya terdapat tiga sumber alam fikiran Islam, yaitu (1) sumber Islam yang murni dan sejati (al-Qur'an dan al-Hadith), (2) rakyat-rakyat yang telah mempunyai kebudayaan lalu masuk Islam di kalangan mereka, dan (3) bahan-bahan terjemahan dari bahasa asing ke dalam bahasa Arab. ${ }^{10}$

Sejalan dengan pemikiran di atas, menurut penulis, pendidikan diniyah atau madrasah diniyah diselenggarakan oleh umat Islam juga mengacu pada ayat-ayat al-Qur'an dan al-hadith sebagai landasan pokok dalam Islam. Berikut ini penulis sajikan beberapa ayat dan hadith yang penulis anggap dapat menjadi landasan pemikiran dan operasional pendidikan diniyah pada umumnya dan madrasah diniyah pada khususnya. Tidak hanya alQur'an dan al-hadith, akan kami sajikan juga beberapa peraturan perundang-undangan yang dianggap sebagai rujukan ideologis bagi madrasah diniyah sehingga penyelenggaraan diniyah memiliki urgensi bagi umat Islam.

1. al-Qur'an

a. QS. Al-'Alaq (96: 1-5): "Bacalah dengan (menyebut) nama Tuhanmu Yang Menciptakan. Dia telah menciptakan manusia dari segumpal darah. Bacalah, dan Tuhanmu-lah Yang Maha Pemurah. Yang mengajar (manusia) dengan perantaraan kalam. Dia mengajarkan kepada manusia apa yang tidak diketahuinya".11

b. QS. Al-Baqarah (2: 269): "Allah menganugerahkan alHikmah (kefahaman yang dalam tentang al-Qur'an dan asSunnah) kepada siapa yang Dia kehendaki. Dan barangsiapa yang dianugerahi al-Hikmah, dia benar-benar telah dianugerahi karunia yang banyak. Dan hanya orang-orang yang berakallah yang dapat mengambil pelajaran (dari firman Allah)".12

c. QS. Al-Nisa' (4: 162): “Tetapi orang-orang yang mendalam ilmunya di antara mereka dan orang-orang mukmin, mereka beriman kepada apa yang telah diturunkan kepadamu (Al Quran), dan apa yang telah diturunkan sebelummu dan orang-orang yang mendirikan shalat, menunaikan zakat, dan

10 M.M. Sharif, Alam Fikiran Islam. Penerj. Prof. Dr. Fuad Moh. Fachruddin (Bandung: CV. Diponegoro, 1979), 28-50.

11 Departemen Agama RI, Al-Qur'an dan Terjemahnya (Surabaya: Al-Hidayah, 2002), 1079.

12 Ibid., 67. 
yang beriman kepada Allah dan hari kemudian. Orang-orang itulah yang akan Kami berikan kepada mereka pahala yang besar".13

d. QS. Al-An'am (6: 50): “Katakanlah: Aku tidak mengatakan kepadamu, bahwa perbendaharaan Allah ada padaku, dan tidak (pula) aku mengetahui yang ghaib dan tidak (pula) aku mengatakan kepadamu bahwa aku seorang malaikat. Aku tidak mengikuti kecuali apa yang diwahyukan kepadaku. Katakanlah: "Apakah sama orang yang buta dengan yang melihat?" Maka apakah kamu tidak memikirkan(nya)?".14

e. QS. Saba' (34: 6): "Dan orang-orang yang diberi ilmu (Ahli Kitab) berpendapat, bahwa wahyu yang diturunkan kepadamu dari Rabb-mu, itulah yang benar, dan menunjuki (manusia) kepada jalan Rabb Yang Maha Perkasa lagi Maha Terpuji". ${ }^{15}$

f. QS. Al-Zumar (39: 9): “(Apakah kamu hai orang musyrik yang lebih beruntung) ataukah orang yang beribadat di waktu-waktu malam dengan sujud dan berdiri, sedang ia takut kepada (azab) akhirat dan mengharapkan rahmat Tuhannya? Katakanlah: "Adakah sama orang-orang yang mengetahui dengan orang-orang yang tidak mengetahui?" Sesungguhnya orang yang berakallah yang dapat menerima pelajaran". ${ }^{16}$

g. QS. Al-Jathiyah (45: 17): "Dan Kami berikan kepada mereka keterangan-keterangan yang nyata tentang urusan (agama); maka mereka tidak berselisih melainkan sesudah datang kepada mereka pengetahuan karena kedengkian yang ada di antara mereka. Sesungguhnya Tuhanmu akan memutuskan antara mereka pada hari kiamat terhadap apa yang mereka selalu berselisih padanya". ${ }^{17}$

h. QS. Al-Taubah (9: 122): "Tidak sepatutnya bagi mukminin itu pergi semuanya (ke medan perang). Mengapa tidak pergi dari tiap-tiap golongan di antara mereka beberapa orang untuk memperdalam pengetahuan mereka tentang agama dan untuk memberi peringatan kepada kaumnya apabila mereka telah kembali kepadanya, supaya mereka itu dapat menjaga dirinya". ${ }^{18}$

\footnotetext{
13 Ibid., 150.

14 Ibid., 194

15 Ibid., 684.

16 Ibid., 747.

17 Ibid., 817.

18 Ibid., 301.
} 
i. QS. Al-Mujadilah (58: 11): "Hai orang-orang beriman apabila dikatakan kepadamu: "Berlapang-lapanglah dalam majlis", maka lapangkanlah niscaya Allah akan memberi kelapangan untukmu. Dan apabila dikatakan: "Berdirilah kamu", maka berdirilah, niscaya Allah akan meninggikan orang-orang yang beriman di antaramu dan orang-orang yang diberi ilmu pengetahuan beberapa derajat. Dan Allah Maha Mengetahui apa yang kamu kerjakan". ${ }^{19}$

2. al-Hadits

a. "Barang siapa yang melalui sebuah jalan untuk mencari ilmu maka Allah memudahkannya mendapatkan jalan menuju surga". ${ }^{20}$

b. "Sesungguhnya ilmu (diperoleh) dengan belajar". ${ }^{21}$

c. "Jika Allah menghendaki sesorang menjadi baik maka Allah akan memahamkannya dalam (ilmu) agama". ${ }^{22}$

d. "Tidak (diperbolehkan) iri kecuali dalam dua hal. Pertama, (seorang) laki-laki yang Allah memberikan harta kepada kemudian dia menggunakannya di dalam kebaikan. Kedua, (seorang) laki-laki yang Allah memberikan kepada hikmah (ilmu) dan dia mengamalkannya dan mengajarkannya". ${ }^{23}$

e. "Sesungguhnya sebagian dari syarat (terjadinya) kiamat adalah hilangnya ilmu, meratanya kebodohan, (meluasnya) meminum khamar, dan (dilakuakannya) zina secara terang-terangan". ${ }^{24}$

f. "Sesungguhnya Allah tidak menghilangkan ilmu begitu saja dari manusia, melainkan Allah menghilangkan ilmu dengan cara mennghilangkan ulama'. Ketika ulama' telah tidak tersisa maka manusia menjadikan orang-orang bodoh sebagai pemimpin. Maka ketika manusia bertanya kepada mereka, maka mereka meberikan fatwa tanpa didasari ilmu. Maka jadilah mereka tersesat dan menyesatkan". ${ }^{25}$

\footnotetext{
19 Ibid., 910.

20 Abū 'Abdillah Muhammad bin Ismāil al-Bukhārī, Matn al-Bukhārī Juz I (Indonesia: al-Haramayn, $\mathrm{tt}$ ), 24

21 Ibid., 24.

22 Ibid., 24.

23 Ibid., 24-25

${ }^{24}$ Ibid., 26.

25 Ibid., 30.
} 
g. "Sesungguhnya terdapat (waktu) beberapa hari sebelum kiamat, di saat itu ilmu akan dihilangkan, kebodohan akan merata, pembunhan akan samakin banyak". ${ }^{26}$

h. "Barang siapa memulai suatu kebaikan di dalam (urusan agam) Islam kemudian orang melakukan seperti itu setelahnya, maka dia mendapatkan pahala sebagaimana orang yang melakukannya dengan tidak mengurangi pahala mereka sedikitpun"... ${ }^{27}$

i. "Mencari ilmu wajib bagi setiap orang Islam". ${ }^{28}$

Dari beberapa ayat al-qur'an dan hadits Nabi di atas dapat dipahami bahwa pendidikan agama Islam merupakan hal pokok bagi umat Islam yang harus diberikan kepada para generasi muslim sebagai manifestasi pengabdian kepada Allah Swt, sehingga madrasah diniyah dapat menjadi salah satu pusat pengetahuan agama Islam. ${ }^{29}$

\section{Perspektif Historis}

Pendidikan Islam, dalam sejarah pertumbuhan dan perkembangannya di Indonesia, berlangsung dari pengajaran yang sederhana seiring dengan perkembangan Islam di masa itu. Kesederhanaan pendidikan Islam itu terlihat dalam pelaksanaan pengajaran dengan sistem halaqah yang dilakukan di tempattempat ibadah, semacam masjid, mushalla, bahkan juga di rumahrumah ulama ${ }^{30}$ Dalam perkembangannya serta interaksi Islam dengan budaya lokal yang sudah dimiliki oleh masyarakat praIslam, maka terjadilah adopsi maupun transfer lembaga keagamaan dan sosial yang sudah ada ke dalam lembaga pendidikan Islam. Menurut Hanun Asrohah, di Jawa Islam mentransfer lembaga keagamaan Hindu-Budha menjadi pesantren, umat Islam di Minangkabau mengambil alih surau sebagai peninggalan adat masyarakat setempat menjadi lembaga pendidikan Islam, dan demikian pula masyarakat Aceh dengan

${ }^{26}$ Muslim bin Hujjāj bin Muslim al-Qusyayrỉ al-Naisāburi, S\}ahih Muslīm Juz 2 (Surabaya: al-Hidayah, tt), 463.

27 Ibid., 465.

${ }^{28}$ Abu Bakar Ah\}mad bin al-H\}usayn al-Bayhāqi, Shu'b al-Imān Juz II (Beyrut: Dar al-Kutub al-Alamiyah, $1410 \mathrm{H}$ ), 253.

29 Fathor Rachman dan Ach. Maimun, "Madrasah Diniyah Takmiliyah (MDT) Sebagai Pusat Pegetahuan Agama Masyarakat Pedesaan (Studi Peran MDT di Desa Gapura Timur Gapura Sumenep)", Anil Islam, Vol 9. Nomor 1 Juni (2016), 55-94.

30 Mansur dan Mahfud Junaidi, Rekonstruksi Sejarah Pendidikan Islam (Jakarta: Departemen Agama RI, 2005), 46. 
mentransfer lembaga masyarakat meunasah sebagai lembaga pendidikan Islam. ${ }^{31}$

Sebagaimana dikatakan bahwa madrasah diniyah, jika diartikan secara sederhana, adalah pendidikan khusus agama Islam, maka ketika menilik sejarah madrasah diniyah akan lebih kompleks dari pada madrasah yang diartikan sebagai lembaga pendidikan yang tidak hanya menyajikan pembelajaran agama Islam melainkan juga memberikan pengetahuan umum. Hal ini karena, pendidikan diniyah, atau kalau mau disebut demikian, masjid dan langgar, pesantren, surau, meunasah, rangkang, dayah ${ }^{32}$, yang relevan dengan pengertian madrasah diniyah sebelum mengalami perubahan atau pembaharuan Islam di Indonesia. Karena setelah adanya perubahan dan pembaharuan pendidikan Islam di Indonesia, pesantren dan madrasah diniyah tersebut mengalami metamorfosis dan berubah menjadi madrasah yang tidak khusus mengajarkan ilmu agama Islam, melainkan pengajaran ilmu umum juga diberikan kepada semua santri sesuai dengan jenjangnya. ${ }^{33}$

Menurut Steenbrink ${ }^{34}$, pendidikan Islam hingga awal abad ke20 berlangsung dalam beberapa tingkatan; pertama pengajian alQur'an. Pendidikan ini dianggap sebagai pendidikan yang paling sederhana, seluruhnya berpusat pada pengajian al-Qur'an dan disebut sebagai pengajian al-Qur'an. Inti dari pendidikan ini adalah belajar membaca beberapa bagian dari al-Qur'an khususnya yang dibutuhkan dalam melaksanakan shalat, seperti surat al-Fatihah dan surat-surat pendek pada juz ke 30 dengan cara menghafal. Di samping itu, juga diberikan pengajaran tentang shalat, wudlu dan

\footnotetext{
${ }^{31}$ Hanun Asrohah, Sejarah Pendidikan Islam (Jakarta: Logos Wacana Ilmu, 1999), 144.

32 Haidar Putra Daulay, Sejarah Pertumbuhan dan Pembaruan Pendidikan Islam di Indonesia (Jakarta: Kencana, 2009), 20-28.

33 Menurut Karel A. Steenbrink, perubahan Islam di Indonesia terjadi di awal abad 20 dengan faktor pendorong yang penting, antara lain: (1) semenjak tahun 1900 di beberapa tempat muncul keinginan untuk kembali kepada Qur'an dan Sunnah yang dijadikan titik tolak untuk menilai kebiasaan agama dan kebudayaan yang ada, (2) perlawanan nasional terhadap penguasan Kolonial Belanda, (3) usaha yang kuat dari orang-orang Islam untuk memperkuat organisasinya di bidang sosial ekonomi, baik demi kepentingan mereka sendiri, maupun untuk kepentingan rakyat banyak, dan (4) terjadinya pembaharuan pendidikan Islam, dikarenakan cukup banyak orang yang merasa tidak puas dengan metode tradisonal dalam mempelajari Qur'an dan Studi Agama. Karel A. Steenbrink, Pesantren, Madarasah, Sekolah: Pendidikan Islam dalam Kurun Moderen (Jakarta: LP3ES, 1994), 26-28.

${ }^{34}$ Karel A. Steenbrink, Pesantren, Madarasah, Sekolah ..., 10-20.
} 
beberapa do'a. Pengajian ini dilaksanakan secara individual di langgar, surau, dan di rumah murid tertentu yang orang tuanya memiliki kedudukan penting di tengah masyarakat. Tanda selesai dari proses pendidikan ini adalah ketika seorang murid telah mampu mengkhatamkan bacaan al-Qur'an. ${ }^{35}$ Sedangkan Maksum mangatakan bahwa sebelum abad 20, tradisi pendidikan Islam di Indonesia agaknya tidak mengenal istilah madrasah, kecuali pengajaran al-Qur'an, masjid, pesantren, surau, langgar, dan tajug. ${ }^{36}$ Dari kedua pendapat ini dapat dipahami bahwa baru pada awal abad 20, Indonesia mengenal sistem pendidikan modern madrasah sebagaimana sistem tersebut telah ada di Timur Tengah.

Kedua pengajian kitab. Pendidikan ini disebut sebagai pendidikan lanjutan. Perbedaan yang mencolok dari pola pendidikan ini dengan pendidikan tingkat pertama (pengajian alQur'an) adalah: (a) Para murid pengajian kitab ini pada umumnya masuk asrama dalam lingkungan lembaga pendidikan agama Islam yang disebut pesantren; (b) Mata pelajaran yang diberikan meliputi mata pelajaran yang lebih banyak dari pada pengajian al-Qur'an. Fase pertama pendidikannya pada umumnya dimulai dengan pendidikan bahasa; dan (c) Pendidikan tidak hanya diberikan secara individual, tetapi juga secara berkelompok. Dalam pengajian kitab di tingkat pertama, para santri mempelajari bahasa Arab dengan cara menghafal teks dalam bentuk sajak, syi'ir, atau $n a z\{a m$, kemudian mendapatkan penjelasan dari sang kiyai atau ustadz yang mengajarnya. Belajar bahasa Arab ini kemudian lebih akrab dikenal dengan istilah ilmu nahwu. Setelah menyelesaikan pembelajaran ilmu nahwu dan dianggap menguasai bahasa Arab dengan baik, kemudian santri dapat melanjutkan pembelajarannya dari sang kiyai dengan mengikuti kajian kitab tertentu dan dimulai dengan fiqih, tauhid atau ushuluddin, dan tafsir al-Qur'an. Setelah santri menyelesaikan kajian pokok tersebut baru dapat melanjutkan pada kajian yang lain seperti tasawuf, hadith, hisab atau falak, yang semua itu bergantung pada keahlian yang dimiliki oleh sang kiyai. ${ }^{37}$

35 Bila seorang murid sudah menamatkan pelajarannya, dalam arti sudah dapat membaca Qur'an sampai tamat, maka diadakan selamatan, khataman namanya. I. Djumhur dan H. Danasuparta, Sejarah Pendidikan (Bandung: CV. Ilmu, tt), 112.

36 Maksum, Madrasah: Sejarah dan Perkembangannya (Jakarta: Logos Wacana Ilmu, 1999), 97.

37 Pengajaran yang lebih lanjut dan lebih mendalam ini diberikan di pesantren. I. Djumhur dan H. Danasuparta, Sejarah Pendidikan (Bandung: CV. Ilmu, 1981), 112. 
Dalam perkembangannya, di akhir abad ke-19 dan awal abad ke-20 telah berdiri lembaga pendidikan Islam di Indonesia, antara lain: pada tahun $1899 \mathrm{KH}$. Hasyim Asy'ari mendirikan Pondok Pesantren Tebuireng Jombang; pada tahun 1905 Adipati Sorodinigrat dan R. Panghulu Tafsirul Anam mendirikan Madrasah Mambaul Ulum Surakarta, Jam'iyah al-Khairiyah mendirikan Madrasah Jami'at Khair Jakarta; pada tahun 1907 Abdullah Ahmad mendirikan Madrasah Adabiyah Sumatera Barat; pada tahun 1910 M. Thaib Umar mendirikan Madras School Sumatera Barat; pada tahun 1911 KH. Munawir mendirikan Pondok pesantren Krapyak Yogyakarta, pada tahun 1912 berdiri Madrasah Maslurah Tanjung Pura Sumatera Timur, Muhammadiyah mendirikan Madrasah Islamiyah Yogyakarta; pada tahun 1913 Jam'iyah al-Irsyad mendirikan Madrasah al-Irsyad Jakarta, H. Bad. Somad mendirikan Madrasah Nurul Iman Jambi, Syekh Mustafa Husien mendirikan Pesantren dan Madrasah Mustafawiyah Tapanuli; pada tahun 1915 Zainuddin Labay el-Yunusy mendirikan Diniyah School Padang Panjang, Syarikat Islam mendirikan Madrasah Aliyah dan Tsnawiyah Muawanatul Muslimin Kudus Jawa Tengah; pada tahun 1916 KH. M. Yasin dkk., mendirikan Mathlaul Anwar Banten, KH. Hasyim Asy'ari mendirikan Madrasah Salafiyah Tebuireng Jombang, Syekh Hasan Maksum mendirikan Pesantren Syekh Hasan Maksum Sumatera Timur; pada tahun 1917 berdiri Madrasah PUI Majalengka, KH. Abd. Halim mendirikan Madrasah Ibtidaiyah Majalengka; pada tahun 1918 berdiri Madrasah Aziziyah Sumatera Timur, Ahmad Dahlan mendirikan Madrasah Muhammadiyah Yogyakarta, Syekh Abbas mendirikan Arabiyah School Ladang Lawas, Mahmud Yunus mendirikan Diniyah School Sumatera Barat, berdiri al-Najah al-Falah Sei-Kalimantan, KHR. Aswawi mendirikan Madrasah Kudsiyah Kudus Jawa Tengah, berdiri Madrasah al-Sultaniyah Sambas Kalimantan Barat; pada tahun 1919 KH. Wahab Hasbullah mendirikan Pondok Pesantren Tambak Beras Jombang, KH. Tamim mendirikan Pondok Pesantren Rejoso Paterongan; pada tahun $1920 \mathrm{KH}$. Moh. Yunus mendirikan Madrasah al-Qur'aniyah Palembang, K. Amagus H. Nanang Misri mendirikan Madrasah Ahliyah Diniyah Palembang; pada tahun 1921 HAMKA mendirikan Sumatera Thawalib Padang Panjang; pada tahun 1922 H. Achmad Syakur mendirikan Madrasah Sa'adah ad-Darain, H. Abd. Majid mendirikan Madrasah Nurul Islam Jambi; pada tahun 1923 Rahmah el-Yunusiyah mendirikan Diniyah Putri Padang Panjang, KH. Ahmad Sanusi mendirikan Pesantren dan Madrsah Gunung Puyuh Sukabumi Jabar; pada tahun 1925 Jam'iyah 
al-Khairiyah mendirikan Madrasah al-Khairiyah Banten; pada tahun 1926 KH. Imam Zarkasyi mendirikan Pesantren Modern Gontor Ponorogo Jawa Timur; pada tahun 1928 KH. A. Khaliq mendirikan Madrasah Tasywiqut Tullab Kudus Jawa Tengah, H. Abd. Rasyid mendirikan Madrasah Formal Islam Amuntai Kalimantan Selatan; pada tahun 1930 Tengku Muhammad Daud Beureuh mendirikan Madrasah Sa'adah Adabiyah Aceh, Tengku Abdurrahman Meunasah Mancap mendirikan Madrasah al-Muslim Aceh, Syekh al-Idrus mendirikan Madrasah al-Khairat Sulawesi; pada tahun 1931 Syekh H. M. As'ad Bugis mendirikan Madrasah Wejo Tarbiyah Islamiyah Sengkang Sulawesi; pada tahun 1933 Persatuan Umat dan Pemuka Rakyat mendirikan Madrasah Amiriyah Islamiyah Bone Sulawesi;pada tahun 1934 KH. Abu Bakar Bastari mendirikan Madrasah Nurul Falah Palembang; pada tahun 1936 A. Hasan mendirikan Pesantren Persatuan Islam Bandung, KH. Zainuddin Pancor mendirikan Madrasah Nahdlatul Wathan Lombok Timur, berdiri Madrasah al-Ittihad Ampenan Lombok Barat, beridiri Madrasah Darul Ulum Sumbawa, berdiri Madrasah al-Roudlotul Islamiyah Pontianak Kalimantan; pada tahun 1938 KH. Ibrahim mendirikan Madrasah Darul Funun Palembang, H. Abdurrahman Ambu Dale mendirikan Madrasah Tarbiyah Islamiyah Mangkoso Sulawesi Tengah, dan berdiri Madrasah Ma'ahidud Diniyah Kudus Jawa Tengah. ${ }^{38}$

Memang, dari sekian lembaga pendidikan Islam di atas tidak semuanya adalah murni diniyah, tetapi semua itu berakar dari pendidikan diniyah yang terbangun sejak sebelum itu. Sebagaimana dikatakan oleh Muhammad Daud, bahwa isi kurikulum madrasah pada umumnya adalah yang diajarkan di lembaga-lembaga pendidikan Islam (surau dan pesantren) ditambah dengan beberapa materi pelajaran yang disebut dengan ilmu-ilmu umum. ${ }^{39}$

Menurut Dawam Raharjo, di awal abad ke-20 hingga awal kemerdekaan, pendidikan Islam di Indonesia diselenggarakan dengan sangat dikotomis. Di saat itu, sudah ada yang mengembangkan madrasah yang khusus mengajarkan ilmu keagamaan, namun ada pula madrasah-madrasah yang megajarkan

38 Isti'anah Abu Bakar, "Kelembagaan Madrasah di Indonesia”, Madrasah, Vol. 3 No. 1 (Juli-Desember, 2010), 407., Zuhairini dkk., Sejarah Pendidikan Islam (Jakarta: Bumi Aksara, 1985), 192-196., Maksum, Madrasah: Sejarah dan Perkembangannya (Jakarta: Logos Wacana Ilmu, 1999), 99-111.

39 Abasri, "Sejarah dan Dinamika Lembaga-Lembaga Pendidikan Islam di Nusantara: Surau, Meunasah, Pesantren dan Madrasah", dalam Sejarah Pendidikan Islam, ed. Samsul Nizar (Jakarta: Kencana, 2008), 291. 
ilmu pengetahuan umum. ${ }^{40}$ Meskipun begitu, perubahan pada madrasah diniyah menjadi madrasah formal tidak terjadi secara sekaligus. Karena sesungguhnya di antara praktisi pendidikan ketika itu, para kiyai-ulama, terutama di masa penjajahan Belanda dan Jepang, masih terdapat sebagian yang ingin umat Islam terpisah jauh dari bangsa penjajah, termasuk juga dalam masalah pendidikan. Kondisi ini terus berlangsung hingga Indonesia merdeka.

Menurut Karel A. Steenbrink, secara formal perubahan sistem pendidikan di kalangan umat Islam - madrasah dan pesantren dimulai sejak lahirnya garis besar pendidikan nasional yang merupakan keputusan rapat Badan Pekerja Komite Nasional Pusat (BPKNP) pada tanggal 27 Desember 1945. Pada poin 9 dari usulan BPKNP berbunyi: "kualitas pesantren dan madrasah harus diperbaiki". ${ }^{41}$ Substansi dari poin ini dapat berupa keinginan untuk mengubah wajah materi pendidikan di pesantren dan madrasah yang hanya mementingkan pendidikan agama Islam saja menjadi memlliki perhatian terhadap pengetahuan umum. Selain dari itu pula, pesantren dan madrasah diharapkan dapat menyesuaikan perkembangan metodologi pengajaran, tidak hanya sorogan, dan

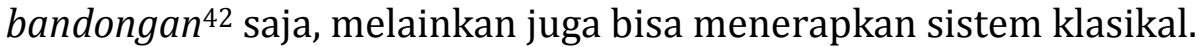

Steenbrink menambahkan bahwa kebanyakan lembaga pendidikan Islam memilih satu jalan lain, misalnya, sejumlah lembaga pengajian Qur'an yang sederhana, serta sejumlah pesantren tidak mengadakan perubahan sebelum 1945. Tetapi sejumlah besar lainnya makin lama makin berkembang dengan mengubah metode, memasukkan sistem klasikal, dengan mengubah isi pendidikan, memberikan pendidikan umum di samping agama yang merupakan bagian yang paling penting dalam

40 Dawam Raharjo, Intelektual Inteligensia dan Perilaku Politik Bangsa (Bandung: Mizan, 1993), 33-36.

${ }^{41}$ Karel A. Steenbrink, Pesantren, Madrasah, Sekolah ..., 90-91.

42 Sorogan adalah sistem pembelajaran individual dalam sistem pendidikan pesantren yang diberikan dalam pengajian kepada murid-murid yang telah menguasai pembacaan Qur'an. Bandongan atau seringkali disebut sistem wetonan adalah metode pengajaran di lingkungan pesantren di mana sekelompok murid (antara 5 sampai 500 murid) mendengarkan seorang guru yang membaca, menerjemahkan, menerangkan, bahkan seringkali mengulas buku-buku Islam dalam bahasa Arab. Zamakhsyari Dhofier, Tradisi Pesantren: Studi Pandangan Hidup Kyai dan Visinya Mengenai Masa Depan Indonesia (Jakarta: LP3Es, 2011), 54. 
kurikulumnya. ${ }^{43}$ Sistem pendidikan ini kemudian disebut dengan madrasah.

Madrasah menjadi pilihan umat Islam Indonesia dalam mengembangkan pendidikan dipengaruhi oleh dua faktor penting; pertama karena pendidikan Islam tradisional (oleh umat Islam) dianggap kurang sistematis dan kurang memberikan kemampuan pragmatis yang memadai; dan kedua karena laju perkembangan sekolah-sekolah ala Belanda di kalangan masyarakat cenderung meluas dan membawakan watak sekularisme sehingga harus diimbangi dengan sistem pendidikan Islam yang memiliki model dan organisasi yang lebih teratur dan terencana. ${ }^{44}$

Perubahan sistem pendidikan Islam tradisional ke modern, salah satunya digunakannya madrasah dalam pendidikan Islam, melahirkan problematika baru dalam pendidikan Islam. Problem tersebut antara lain memunculkan pemikiran dan sikap dikotomi ilmu dan sistem pendidikan. Menurut Maksum, pada masa pemerintahan Orde Baru, dunia pendidikan di Indonesia berkembang dalam sistem dualistik antara pendidikan umum (nasional) di satu pihak dan pendidikan agama (Islam) di lain pihak, dengan posisi pendidikan umum jauh lebih dominan. ${ }^{45}$ Untuk menegaskan keberadaan madrasah diniyah dalam sistem pendidikan nasional, Menteri Agama mengeluarkan regulasi dengan Keputusan Menteri Agama Nomor 13 Tahun 1964 tentang Kurikulum Madrasah Diniyah. ${ }^{46}$ Regulasi ini dikeluarkan untuk menegaskan distinction madrasah diniyah dengan madrasah dan sekolah.

Merujuk pada penjelasan di atas, penulis berkesimpulan bahwa istilah madrasah diniyah digunakan secara resmi dalam sistem pendidikan nasional adalah semenjak dikeluarkannya Keputusan Menteri Agama Nomor 13 Tahun 1964 tentang Kurikulum Madrasah Diniyah. Jadi madrasah diniyah merupakan pilihan sistem pendidikan Islam selain madrasah dalam rangka mengakomodir pemikiran dan keinginan sebagian masyarakat Islam Indonesia untuk memiliki model pendidikan yang khusus mengajarkan ilmu agama Islam selain pesantren yang dapat dikelola dengan manajemen pendidikan modern. Namun demikian, pada saat ini, madrasah diniyah masih tergolong pendidikan non formal.

\footnotetext{
${ }^{43}$ Karel A. Steenbrink, Pesantren, Madarasah, Sekolah ..., 87-88.

44 Maksum, Madrasah: ..., 114.

45 Ibid., 113.

46 Karel A. Steenbrink, Pesantren, Madrassah, Sekolah ... , 167-168.
} 
Kemudian, pada era reformasi, lahir UU No. 20 Tahun 2003 tentang SisitemPendidikan Nasional, dari UU ini lahir PP No. 55 Tahun 2007 tentang Pendidikan Agama dan Pendidikan Keagamaan, setelah PP ini kemudian lahir Peraturan Menteri Agama Nomor 13 Tahun 2014 tentang Pendidikan Keagamaan Islam. Peraturan ini bertujuan menguatkan posisi madrasah diniyah dalam sistem pendidikan nasional serta menegaskan bahwa madrasah diniyah menjadi bagian dari pendidikan formal. Yang artinya, bahwa madrasah diniyah formal memiliki kedudukan fungsional sama dengan madrasah dan sekolah, namun memiliki ciri khusus yang berbeda dengan madrasah dan sekolah. ${ }^{47}$

\section{Perspektif Politik}

Adapun dasar penyelenggaraan pendidikan diniyah atau madrasah diniyah menurut peraturan perundang-undangan yang berlaku di Negara Indonesia adalah sebagai berikut: UndangUndang Dasar Tahun 1945, pasal 28C, pasal 28E, pasal 29 (2); Undang-Undang Nomor 20 Tahun 2003 tentang Sistem Pendidikan Nasional (SPN), pasal 1, pasal 3, pasal 4, pasal 5, pasal 6, pasal 7, pasal 8, pasal 9, pasal 10, pasal 11, pasal 13, pasal 14, pasal 15, pasal 16, pasal 26, pasal 30, pasal 46, 54, dan pasal 55; Peraturan Pemerintah Nomor 55 Tahun 2007 tentang Pendidikan Agama dan Pendidikan Keagamaan, pasal 1, pasal 14, pasal 21, dan pasal 25; Keputusan Menteri Agama Nomor 13 Tahun 1964 tentang Kurikulum Madrasah Diniyah yang telah diubah dan disempurnakan terakhir dengan dengan Peraturan Menteri Agama Nomor 3 Tahun 1983 tentang Kurikulum Madrasah Diniyah; Peraturan Menteri Agama Nomor 13 Tahun 2014 tentang Pendidikan Keagamaan Islam, pasal 1, pasal 20, pasal 45, pasal 46, pasal 47, pasal 48, pasal 49, pasal 53, dan pasal 54; Keputusan Menteri Agama Nomor 18 Tahun 1985 tentang Susunan Organisasi dan Tata Kerja Departemen Agama yang telah diubah dan disempurnakan terakhir dengan Keputusan Menteri Agama Nomor 3 Tahun 2006; Peraturan Menteri Agama No. 13 Tahun 2014 tentang Pendidikan Keagamaan Islam. 48 Oleh karena itu,

\footnotetext{
${ }^{47}$ Badrudin, "Indonesia's Educational Policies on Madrasah Diniyah (MD)”, Jurnal Pendidikan Islam, Vol. 3 Nomor 1 (2017), 17-32.

48 Landasan ini dapat dilihat pada dasar hukum penyusuan Pedoman Penyelenggaraan Madrasah Diniyah Takmiliyah Kementerian Agama Tahun 2014, namun di sana tidak terperinci menurut pasal yang memuat aturan tentang madrasah diniyah. Kementerian Agama RI, Pedoman Penyelenggaraan
} 
pengembangan madrasah diniyah di Indonesia telah memiliki legalitas formal. Hal ini pula menunjukkan bahwa pegembangan madrasah diniyah di Indonesia memiliki urgensi dalam sisitem pendidikan nasional.

Sejalan dengan penerapan desentralisasi pemerintahan dalam bentuk otonomi daerah, maka pemerintah daerah membentuk peraturan daerah dalam rangka merespon penyelenggaran madrasah diniyah. Beberapa daerah yang telah mengeluarkan kebijakannya dalam bentuk peraturan daerah maupun peraturan bupati, antara lain: Kota Medan ${ }^{49}$, Kabupaten Pandeglang50, Kota Serang51, Kabupaten Bogor ${ }^{52}$.

\section{Perspektif Manajemen}

Merujuk pada Peraturan Menteri Agama Nomor 13 Tahun 2014 tentang Pendidikan Keagamaan Islam, maka pendidikan diniyah merupakan bagian dari pendidikan keagamaan Islam. Disebutkan dalam Permenag tersebut bahwa pendidikan keagamaan Islam terdiri dari (a) pesantren, dan (b) pendidikan diniyah (pasal 3). Selanjutnya disebutkan bahwa pendidikan diniyah terdiri atas (a) pendidikan diniyah formal, (b) pendidikan diniyah nonformal, dan (c) pendidikan diniyah informal (pasal 20).

Pendidikan diniyah formal adalah lembaga pendidikan keagamaan Islam yang diselenggarakan oleh dan berada di dalam pesantren secara terstruktur dan berjenjang pada jalur pendidikan formal. Pendidikan diniyah nonformal adalah pendidikan keagamaan Islam yang diselenggarakan dalam bentuk Madrasah Diniyah Takmiliyah, Pendidikan Al-Qur'an, Majelis Taklim, atau bentuk lain yang sejenis baik di dalam maupun di luar pesantren pada jalur pendidikan nonformal. Pendidikan diniyah informal adalah pendidikan keagamaan Islam dalam bentuk program yang

Madrasah Diniyah (Surabaya: Kanwil Kementerian Agama Provinsi Jawa Timur, 2015), 3-4.

49 Indra Fauzan dan Zakaria Taher, "Dinamika Pembuatan Peraturan Daerah Wajib Belajar Madrasah Diniyah Takmiliyah Awwaliyah di Kota Medan", Jurnal Ilmiah Mimbar Demokrasi, Vol. 16 Nomor 1 (Oktober 2016), 36-49.

50 M. Fathurrahman, "Efektifitas Implementasi Kebijakan Program Wajib Belajar Madrasah Diniyah Awaliyah di Kabupaten Pandeglang", Tanzhim: Jurnal Penelitian Manajemen Pendidikan, Vol. 1 Nomor 1 (2016), 27-40.

${ }^{51}$ Anis Fauzi dan Cecep Nikmatullah, "Pelaksanaan Pendidikan Madrasah Diniyah di Kota Serang", Jurnal Pendidikan dan Kebudayaan, Vol. 1 Nomor 2 (Agustus 2016), 157-178.

52 Nur Alia, "Madrasah Diniyah Takmiliyah dalam Perspektif Standar Pelayanan Minimal di Kabupaten Bogor", Penamas: Jurnal Penelitian Keagamaan dan Kemasyarakatan, Vol. 29 Nomor 3 (Oktober-Desember 2016), 349-512. 
diselenggarakan di lingkungan pada jalur pendidikan informal (pasal 1).

Sebagaimana topik kajian ini adalah tentang madrasah diniyah, maka selanjutnya dengan tetap merujuk pada Permenag Nomor 13 Tahun 2014 tentang Pendidikan Keagamaan Islam, bahwa pendidikan diniyah nonformal diselenggarakan dalam bentuk: (a) madrasah dniyah takmiliyah, (b) pendidikan al-Qur'an, (c) majelis taklim, dan (d) pendidikan keagamaan Islam lainnya (pasal 45). Maka, madrasah diniyah takmiliyah adalah lembaga pendidikan keagamaan Islam pada jalur pendidikan nonformal yang diselenggarakan secara terstruktur dan berjenjang sebagai pelengkap pelaksanaan pendidikan Agama Islam pada jenjang pendidikan dasar, menengah, dan tinggi (pasal 1).

Oleh karena itu, maka madarasah diniyah takmiliyah diselenggarakan dengan tujuan untuk melengkapi, memperkaya, dan memperdalam pendidikan agama Islam bagi peserta didik MI/SD, MTs/SMP, MS/SMA/SMK/MAK, dan pendidikan tinggi atau yang sederajat dalam rangka peningkatan keimanan dan ketakwaan peserta didik kepada Allah SWT. Madrasah diniyah memiliki jenjang ula, wustha, ulya, dan al-Jami'ah. Jenjang ula diikuti oleh peserta didik MI/SD atau yang sederajat. Jenjang wustha diikuti oleh peserta didik MTs/SMP atau yang sederajat. Jenjang ulya diikuti oleh peserta didik MA/SMA/MAK/SMK atau yang sederajat. Dan jenjang al-Jami'ah diikuti oleh peserta didik pada pendidikan tinggi (pasal 46). Madrasah diniyah ini diselenggrakan oleh masyarakat secara mandiri maupun terpadu dengan satuan pendidikan lainnya (pasal 47). Sedangkan kurikulum madrasah diniyah takmiliyah ini terdiri atas mata pelajaran pendidikan keagamaan Islam yang paling sedikit meliputi: (a) al-Qur'an, (b) al-Hadith, (c) Fiqih, (d) Akhlaq, (d) Sejarah Kebudayaan Islam, dan (e) Bahasa Arab (pasal 48).

Sedangkan menurut Karel A. Steenbrink dengan merujuk pada Keputusan Menteri Agama tahun 1964, kurikulum madrasah diniyah adalah sebagai berikut:

a. Diniyah Ula: Membaca al-Qur'an 3 jam perminggu, tauhid 3 jam perminggu, fiqih 2 jam perminggu, dan akhlak 2 jam perminggu.

b. Diniyah Wustho: di kelas I dilaksanakan pembelajaran: alQur'an dan al-Hadith 3 jam perminggu, tauhid 3 jam perminggu, fiqih 1 jam perminggu, sejarah Islam 2 jam perminggu, dan akhlak 1 jam perminggu. Di kelas II dilaksanakan pembelajaran; al-Qur'an dan al-Hadith 3 jam 
perminggu, tauhid 3 jam perminggu, fiqih 1 jam perminggu, sejarah Islam 3 jam perminggu, dan akhlak 1 jam perminggu. Di kelas III dilaksanakan pembelajaran; al-Qur'an dan alHadith 3 jam perminggu, tauhid 3 jam perminggu, fiqih 1 jam perminggu, sejarah Islam 3 jam perminggu, dan akhlak 1 jam perminggu.

c. Diniyah Aliyah: di kelas I dilaksanakan pembelajaran: alQur'an dan al-Hadith 3 jam perminggu, tauhid 2 jam perminggu, fiqih 3 jam perminggu, sejarah Islam 1 jam perminggu, dan akhlak 1 jam perminggu. Di kelas II dilaksanakan pembelajaran; al-Qur'an dan al-Hadith 3 jam perminggu, tauhid 2 jam perminggu, fiqih 3 jam perminggu, sejarah Islam 1 jam perminggu, dan akhlak 1 jam perminggu. Di kelas III dilaksanakan pembelajaran; al-Qur'an dan alHadith 3 jam perminggu, tauhid 2 jam perminggu, fiqih 3 jam perminggu, sejarah Islam 1 jam perminggu, dan akhlak 1 jam perminggu. ${ }^{53}$

Kemudian Kementerian Agama melakukan penyempurnaan dalam kurikulum madrasah diniyah, sehingga ditemukan struktur kurikulum madrasah diniyah takmiliyah dibagi dalam 3 kelompok; kelompok mata pelajaran keagamaan, kelompok mata pelajaran bahasa, dan kelompok mata pelajaran muatan lokal. Struktur tersebut dapat dirinci sebagai berikut:

a. MDTA: kelompok mata pelajaran keagamaan terdiri dari mata pelajaran al-Qur'an 5 jam perminggu di kelas I dan II, 4 jam perminggu di kelas III dan IV; mata pelajaran al-Hadith 1 jam perminggu di kelas I dan II, 2 jam perminggu di kelas III dan IV; mata pelajaran aqidah 2 jam perminggu di kelas I-IV; mata pelajaran fiqih 4 jam perminggu di kelas I-IV, dan mata pelajaran tarikh Islam 1 jam perminggu di kelas I-IV. Kelompok mata pelajaran bahasa terdiri dari mata pelajaran bahasa Arab 4 jam perminggu di kelas I-IV. Kelompok mata pelajaran muatan lokal terdiri dari mata pelajaran Arab pegon, imla' dan lain-lain yang sepenuhnya diserahkan kepada madrasah yang bersangkutan, termasuk juga jam perminggunya.

b. MDTW: kelompok mata pelajaran keagamaan terdiri dari mata pelajaran al-Qur'an 3 jam perminggu di kelas I-II; mata pelajaran al-Hadith 2 jam perminggu di kelas I-II; mata pelajaran aqidah 1 jam perminggu di kelas I-II; mata pelajaran fiqih 4 jam perminggu di kelas I-II; dan mata

${ }^{53}$ Karel A. Steenbrink, Pesantren, Madrasah, Sekolah ... , 167-168. 
pelajaran tarikh Islam 2 jam perminggu di kelas I-II. Kelompok mata pelajaran bahasa terdiri dari mata pelajaran bahasa Arab 4 jam perminggu di kelas I-II. Kelompok mata pelajaran muatan lokal terdiri dari mata pelajaran Arab pegon, imla' dan lain-lain yang sepenuhnya diserahkan kepada madrasah yang bersangkutan, termasuk juga jam perminggunya.

c. MDTA: kelompok mata pelajaran keagamaan terdiri dari mata pelajaran al-Qur'an 2 jam perminggu di kelas I-II; mata pelajaran al-Hadith 2 jam perminggu di kelas I-II; mata pelajaran aqidah 2 jam perminggu di kelas I-II; mata pelajaran fiqih 4 jam perminggu di kelas I-II; dan mata pelajaran tarikh Islam 2 jam perminggu di kelas I-II. Kelompok mata pelajaran bahasa terdiri dari mata pelajaran bahasa Arab 4 jam perminggu di kelas I-II. Kelompok mata pelajaran muatan lokal terdiri dari mata pelajaran Arab pegon, imla' dan lain-lain yang sepenuhnya diserahkan kepada madrasah yang bersangkutan, termasuk juga jam perminggunya.

Ketentuan alokasi waktu untuk setiap jam pelajaran dari mata pelajaran tersebut adalah; MDTA (Madrasah Diniyah Takmiliyah Awwaliyah) Kelas I adalah 30 menit; MDTA Kelas II s.d. IV adalah 40 menit; MDTW (Madarasah Diniyah Takmiliyah Wustho) Kelas I s.d. II adalah 45 menit; MDTU (Madrasah Diniyah Takmiliyah Ulya) Kelas I s.d. II adalah 45 menit. ${ }^{4}$ Dalam realisasinya madrasah diniyah masih menghadapi berbagai kendala manajemen, terutama di bidang personalia. Dalam hal ini manajemen madrasah diniyah belum terisi oleh para profesional, sehingga pelaksanaan manajemen madrasah diniyah masih bersifat ala kadarnya. ${ }^{55}$ Namun demikian, terdapat pula madrasah diniyah yang memiliki keunggulan di bandingkan dengan madrasah diniyah lainnya, misalkan madrasah diniyah Miftahul Huda Sumurpangganng Margadana Tegal Jawa Tengah. Madrasah diniyah ini tergolong unggulan karena menerapkan manajemen

54 Kementerian Agama RI, Pedoman Penyelenggaraan Madrasah Diniyah (Surabaya: Kanwil Kementerian Agama Provinsi Jawa Timur, 2015), 23.

55 Nuriyatun Nizah, "Dinamika Madrasah Diniyah: Suatu Tinjauan Historis", Edukasi: Jurnal Penelitian Pendidikan Islam, Vol. 11 Nomor 1 (Februari 2016), 181-202. 
dan pembelajaran layaknya madrasah/sekolah unggulan pada umumnya. ${ }^{56}$

\section{Perspektif Metodologis}

Dalam pembahasan berikut ini, penulis akan menjelaskan strategi dan metode pembelajaran di madrasah diniyah. Namun sebelum itu perlu ditegaskan bahwa kondisi pembelajaran di madarasah diniyah saat ini berbeda jauh dengan kondisi pembelajaran madrasah diniyah di saat awal perkembangan dan pertumbuhannya. Karena di awal pertumbuhan dan perkembangannya, madrasah diniyah masih tradisional dalam penerapan strategi dan metode pembelajaran. Sebagaimana dikatakan oleh Wina Senjaya, Strategi pembelajaran adalah suatu kegiatan pembelajaran yang harus dikerjakan oleh guru dan siswa agar tujuan pembelajaran dapat dicapai secara efektif dan efisien. ${ }^{57}$

Dijelaskan lebih lanjut oleh J.R. David, bahwa dalam strategi pembelajaran terkandunng makna perencanaan. Artinya, bahwa strategi pada dasarnya masih bersifat konseptual tentang keputusan-keputusan yang akan diambil dalam suatu pelaksanaan pembelajaran. ${ }^{58}$ Dalam hal penerapan strategi pembelajaran dalam arti perencanaan, maka madrasah diniyah di masa awal belum menunjukkan penerapan strategi pembelajaran modern, atau bahkan belum memiliki strategi pembelajaran sebagaimana term yang dimaksud. Karena di masa awal madrasah diniyah hanya mengajarkan materi agama Islam dengan mengacu pada kitab kuning klasik yang sudah tersedia. Di sana pendidik tidak melakukan penyusunan materi tertentu untuk disampaikan kepada peserta didik karena materi yang disampaikan mengikuti urutan materi yang tertulis dalam kitab yang menjadi kajian.

Begitu pula dalam konteks metode pembelajaran. Merujuk pada pendapat Ramayulis, metode pembelajaran adalah cara yang dipergunakan oleh pendidik dalam mengadakan hubungan saat berlangsungnya proses pembelajaran. ${ }^{59}$ Dalam pengertian ini terlihat bahwa dalam sebuah pembelajaran harus diupayakan berlangsung hubungan atau komunikasi yang relevan dengan

\footnotetext{
56 Ahmad Syahri, "Penerapan Madrasah Unggulan di Madrasah Miftahul Huda Sumurpangganng Margadana Tegal Jawa Tengah", Al-Wijdan: Journal of Islamic Education Studies, Vol. 1 Nomor 1 (November 2016), 95-108.

57 www.akhmadsudrajat.wordpress.com (diunduh pada tanggal 13 Agustus 2016).

58 Ibid.

59 Ramayulis, Metodologi Pendidikan Agama Islam (Jakarta: Kalam Mulia, 2010), 3.
} 
pertumbuhan dan perkembangan siswa, bukan hanya sekedar memperhatikan materi pembelajaran saja. Sebuah pembelajaran dengan menerapkan metode pembelajaran yang baik dan tepat akan mengantarkan siswa pada pencapaian tujuan pembelajaran tanpa terjadi perusakan pada fitrah pertumbuhan dan perkembangan siswa baik fisik maupun psikis. Pada masal awal tersebut, madrasah diniyah masih tradisional sekali dengan hanya menerapkan metode pembelajaran pesantren yang dikenal dengan sorogan, dan bandongan. Sorogan adalah sistem pembelajaran individual dalam sistem pendidikan pesantren yang diberikan dalam pengajian kepada murid-murid yang telah menguasai pembacaan Qur'an. Bandongan atau seringkali disebut sistem wetonan adalah metode pengajaran di lingkungan pesantren di mana sekelompok murid (antara 5 sampai 500 murid) mendengarkan seorang guru yang membaca, menerjemahkan, menerangkan, bahkan seringkali mengulas buku-buku Islam dalam bahasa Arab. 60

Metode pembelajaran sorogan maupun bandongan bukan tidak memiliki kelebihan dibandingkan dengan metode pembelajaran modern yang saat ini banyak diimplementasikan, namun juga terdapat kelemahan yaitu dalam metode pembelajaran ini belum terlihat adanya eksplorasi potensi yang dimiliki oleh siswa, sehingga siswa tidak mengalami self education tentang materi pembelajaran, mereka cenderung stagnant hanya menerima setiap pemikiran dari sang guru. Menurut Mujamil Qomar, aplikasi metode sorogan membutuhkan waktu yang lama, yang berarti pemborosan, kurang afektif dan efisien. ${ }^{61}$ Begitu pula metode bandongan atau wetonan mengakibatkan santri pasif, karena kreativitas dalam proses pembelajaran didominasi oleh guru, serta metode ini dianggap tidak memiliki kontrol tujuan pembelajaran yang tegas. ${ }^{62}$

Sebagaimana dijelaskan di muka, bahwa madrasah diniyah merupakan produk adaptasi sistem pendidikan pesantren terhadap perkembangan dunia pendidikan nasional maupun global ketika awal abd ke-20. Oleh karena itu, madrasah diniyah merupakan permulaan bagi pesantren untuk melakukan inovasi, adaptasi maupun kombinasi atas perkembangan dunia pendidikan. Pertama-tama yang dilakukan oleh pesantren dengan madrasah

60 Zamakhsyari Dhofier, Tradisi Pesantren ..., 54.

61 Mujamil Qomar, Pesantren: Dari Transformasi Metodologi Menuju Demokratisasi Institusi (Jakarta: Erlangga, 2007), 143.

62 Ibid. 
diniyah adalah membentuk sistem pembelajaran klasikal (madrasi). ${ }^{63}$ Dengan begitu madrasah diniyah dapat dikatakan sebagai pioner model pembelajaran modern bagi tradisionalisme pesantren.

Perubahan strategi dan metode pembelajaran ini dipengaruhi oleh hasil pertemuan (muktamar 1) Rabitah Ma'ahid pada tahun 1959 yang telah mempraktekkan metode-metode pembelajaran modern, meliputi: metode tanya jawab, diskusi, imla?, mut\}ala'ah/recital, proyek, dialog, karyawisata, hafalan/verbalisme, sosiodrama, widyawisata, problem solving, pemberian situasi, pembiasaan/habituasi, dramatisasi (percontohan tingkah laku), reinforcement, stimulus-respon, dan sistem modul (meskipun agak sulit). ${ }^{64}$ Informasi ini sejalan dengan apa yang ditemukan oleh Karel A. Steenbrink dalam penelitiannya bahwa sejumlah pesantren tidak mengadakan perubahan sebelum tahun 1945. Tetapi sejumlah besar lainnya makin lama makin berkembang dengan mengubah metode, mamasukkan sistem klasikal. ${ }^{65}$

Dalam konteks madrasah diniyah takmiliyah sebagaimana topik dalam diskusi ini, dapat dijelaskan bahwa pembelajaran madrasah diniyah takmiliyah terbagi dalam dua kegiatan, yaitu kurikuler dan ekstrakurikuler. ${ }^{66}$ Pertama, kegiatan kurikuler meliputi kegiatan pembelajaran yang alokasi waktunya telah ditentukan dalam program. Kegiatan kurikuler merupakan pelaksanaan atas struktur kurikulum yang telah ditetapkan untuk mencapai standar kompetensi dan kompetensi dasar dari setiap mata pelajaran. Kegiatan kurikuler merupakan kegiatan tatap muka antara santri dan guru, termasuk di dalamnya tugas mandiri, perbaikan, dan pengayaan. Kegiatan kurikuler harus memperhatikan hal sebagai berikut; (1) Waktu yang terjadwal dalam struktur kurikulum dan optimaslisasi sarana dan media pembelajran yang dimiliki. (2) standar kompetensi mata pelajaran dari masing-masing jenjang pendidikan. (3) Kesesuaian antara sifat mata pelajaran dengan sumber, media, dan metodologi pembelajaran. (4) kesesuaian antara karakteristik dan potensi masing-masing santri dengan aspek pembelajaran yang ditetapkan.

Kegiatan kurikuler dilaksanakan melalui beberapa pendekatan, yaitu: (1) Pendekatan klasikal. Belajar klasikal ditujukan untuk memberikan informasi atau pengantar dalam

\footnotetext{
63 Ibid.

64 Ibid., 151.

${ }^{65}$ Karel A. Steenbrink, Pesaantren, Madrasah, Sekolah ..., 88.

66 Kementerian Agama RI, Pedoman, 28-30.
} 
proses pembelajaran. Bentuk pembelajaran klasikal adalah komunikasi verbal yang dilakukan oleh guru dalam menjelaskan pokok/materi pembahasan yang kemudian diikuti dengan dialog bersama santri. (2) Pendekatan belajar kelompok. Belajar kelompok teruama ditujukan untuk mengembangkan keterampilan santri dalam mendalami dan mengembangkan materi pembelajaran, membangun kemampuan santri dalam berdiskusi, berdialog, dan membangun argumentasi keilmuan. (3) Pendekatan perorangan. Belajar perorangan ditujukan untuk menampung kegiatan perbaikan dan pengayaan, karena diperlukan pendekatan khusus kepada santri yang memiliki karakteristik khusus dalam menangkap dan mencerna pengetahuan yang diajarkan. Bahkan pembelajaran di madrasah diniyah terdapat pula yang menerapkan pendekatan tematik. ${ }^{67}$

Kedua, kegiatan ekstrakurikuler. Kegiatan ekstrakurikuler ialah kegiatan di luar jam mata pelajaran biasa yang dilakukan dengan tujuan untuk memperkuat aspek kognitif, psikomotorik, dan afektif santri. Bentuk kegiatan harus terkait dengan pengembangan diri, baik kepribadian maupun keterampilan di bidang keagamaan. Hal-hal yang harus diperhatikan dalam pelaksanaan kegiatan ekstrakurikuler adalah: (1) Materi kegiatan yang dapat memberi pengayaan bagi santri. (2) Sejauh mungkin tidak terlalu membebani santri. (3) memanfaatkan potensi santri dan lingkungan.

Sejalan dengan pelaksanaan pembelajaran di madrasah diniyah takmiliyah sebagaimana diuraikan di atas, maka terdapa beberapa metode pembelajaran yang relevan diterapkan, antara lain: (1) Metode ceramah. Ceramah adalah sebuah bentuk interaksi atau metode mengajar degan menyampaikan informasi dan pengetahuan melalui penuturan lisan dari guru ke santri.68 (2) Metode disukusi. Diskusi adalah percakapan ilmiyah yang responsive, berisikan pertukaran pendapat yang dijalin dengan pertanyaan-pertanyaan problematik, pemunculan ide-ide, dan pengujian ide-ide ataupun pendapat. (3) Metode demonstrasi. Metode demonstrasi adalah pertunjukan tentang proses terjadinya

67 Atiqullah, "Strategi Pembelajaran Keagamaan Model Tematik di Madrasah Diniyah Takmiliyah An-Nidzamia Palengaan Pamekasan", Nuansa, Vo. 9 Nomor 2 (Juli Desember 2012), 213-234.

68 Kementerian Agama RI, Panduan Model Pembelajaran Efektif Madrasah Diniyah Takmiliyah (Surabaya: Kanwil Kemenag Jawa Timur, 2015), 19. Tentang metode pembelajaran pendidikan Islam dapat dilihat juga pada buku Ramayulis, Metodologi Pendidikan Agama Islam (Jakarta: Kalam Mulia, 2010). 
suatu peristiwa atau benda sampai pada penampilan tingkah laku yang dicontohkan agar apat diketahui dan dipahami oleh santri secara nyata atau tiruannya. (4) Metode praktik atau penampilan. Metode penampilan merupakan pelaksanaan pembelajaran dalam bentuk praktik oleh santri di bawah bimbingan, pengawasan, dan kontrol dari dekat oleh guru. (5) Metode kerja kelompok. Metode kerja kelompok merupakan pelaksanaan pembelajaran di mana santri dalam suatu kelompok dipandang sebagai satu kesatuan, untuk mencari satu tujuan pembelajaran yang tentu dilakukan dengan bergotong royong. (6) Metode pemberian tugas. Metode pemberian tugas adalah cara penyajian bahan pelajaran di mana guru memberikan tugas tertentu agar santri melakukan kegiatan belajar, kemudian harus dipertanggungjawabkan. (7) Metode latihan. Metode latihan/drill/training merupakan suatu cara mengajar yang baik untuk menanamkan kebiasaan-kebiasaan tertentu sehingga menjadi gerak atau pemikiran reflek. (8) Metode asistensi. Metode asistensi adalah proses pembelajaran yang memanfaatkan seorang santri yang telah lulus dalam kompetensi atau latihan tertentu untuk bertindak sebagai asisten guru atau pelatih bagi santri yang lain. 69

Dari uraian tentang pembelajaran di atas dapat dipahami bahwa pada saat ini, madrasah diniyah takmiliyah telah sangat dimungkinkan menerapkan strategi dan metode pembelajaran serupa dengan strategi dan metode pembelajaran pada sistem madrasah/sekolah formal, meskipun pada sebagian pembelajarannya masih tetap mempertahankan metode tradisional sorogan dan bandongan. Sehingga, madrasah diniyah takmiliyah dapat diterima oleh masyarakat sesuai dengan perkembangan dunia pendidikan saat ini.

\section{Kekuatan dan Kelemahan}

a) Potensi Madrasah Diniyah.

Pada dasarnya, potensi yang ada pada madrasah diniyah tidak jauh berbeda dengan potensi pondok pesantren, karena kedua bentuk satuan pendidikan ini sama-sama lembaga pendidikan yang lahir, tumbuh, dan berkembang di tengah-tengah masyarakat, dan dilatarbelakangi oleh kebutuhan masyarakat. Sebagai lembaga pendidikan yang dibutuhkan oleh masyarakat dan murni diselenggarakan oleh swasta kekuatan utama madrasah diniyah adalah ketangguhannya dalam menghadapi permasalahan yang timbul. Meskipun dengan kondisi yang serba kekurangan,

${ }^{69}$ Ibid., 24-46. 
madrasah diniyah ini terus berkembang. Kekuatan lain yang dimiliki madrasah diniyah adalah keabsahannya memilih pola, pendekatan, bahkan sistem pembelajaran yang dipergunakan, tanpa terikat dengan model-model tertentu. ${ }^{70}$

Eksistensi madrasah semakin dibutuhkan tatkala alumni pesantren yang menyelenggarakan pendidikan formal ternyata kurang mampu dalam penguasaan ilmu agama. Dengan kenyataan itu maka keberadaan madrasah diniyah, sebagai penopang dan pendukung pendidikan formal yang ada. Selain itu diharapkan dapat mendukung pengembangan madrasah diniyah di masa-masa mendatang.

b) Kelemahan- Kelemahan Madrasah Diniyah

Agar Madrasah diniyah tidak kehilangan daya tarik, kaitannya dengan kelembagaan dan fungsionalnya, diperlukan adanya perubahan paradigma, bangunan dan kerangka berfikir yang memadai dalam penyelenggaraan pendidikan Islam. Diperlukan pendirian mengenai pandangan manusia, masyarakat dan dunia. Manusia diciptakan didunia diberi tugas Allah sebagai khalifah. Manusia mendapatkan wewenang dan kuasa untuk melaksanakan pendidikan terhadap dirinya sendiri. Dengan demikian, pendidikan merupakan tanggung jawab manusia sendiri untuk dapat mendidik dirinya sendiri, memahami hakikat kemanusiaannya, hakikat hidup dan kehidupannya serta tujuan dan tugas dalam kehidupannya yang kemudian dikenal dengan istilah ontologis, epistemologis dan aksiologis. ${ }^{71}$

Sebagai lembaga pendidikan baik itu formal maupun non formal, pasti mempunyai kelemahan-kelemahan. Meskipun madrasah diniyah dan siswanya semakin meningkat dari tahun ke tahun, sebagai lembaga pendidikan keagamaan yang berbasis pada mayarakat ini tidak berkembang dengan optimal. Sebagian besar diniyah adalah lembaga pendidikan yang melayani lapisan masyarakat yang lemah secara ekonomi atau mereka yang membutuhkan nilai lebih dari agama. Hal ini di satu sisi menempatkan diniyah sebagai penyelamat bagi masyarakat dalam memenuhi kebutuhannya terhadap pendidikan agama, tapi di sisi lain berkembang dengan manajemen dan sumber daya pendidikan (SDM, sarana prasarana, pembiayaan,) yang lemah dan pada akhirnya berdampak pada rendahnya kualitas hasil pendidikan dan

70 Depertemen Agama RI, Pedoman, 25.

71 Moh. Wardi, "Problematika Pendidikan Islam Dan Solusi Alternatifnya (Perspektif Ontologis, Epistemologis dan Aksiologis)" Tadris Jurnal Pendidikan Islam STAIN Pamekasan, Volume 8 Nomor 1 Juni 2013, 68. 
jaminan kelangsungan hidupnya. ${ }^{72}$ Banyak madrasah diniyah yang saat didirikan cukup baik perkembangannya, namun karena keterbatasan sumber daya pendidikan akhirnya mengalami penurunan.

Permasalahan pokok lain, walaupun madrasah diniyah merupakan lembaga pendidikan yang secara historis merupakan bagian penting dalam usaha mencerdasan bangsa, dirasakan perhatian negara dan pemerintah masih rendah. Hal ini tidak saja tampak dalam ketidakjelasan kedudukan dan pengakuan lulusan madrasah diniyah dalam sistem perundang-undangan tentang pendidikan nasional, tetapi juga tampak dalam substansi pelayanan/pembinaan..$^{73}$

Kelemahan lain yang ada pada madrasah diniyah adalah sistem pendidikan yang dimiliki lebih banyak terkesan 'ala kadarnya'. Ada banyak langkah yang bisa ditempuh untuk mewujudkan model pendidikan yang ideal, antara lain: integralisasi sistem pendidikan madrasah diniyah ke dalam sistem pendidikan formal; penerapan menejemen pendidikan secara profesional dalam pengelolaan madrasah diniyah; sistem pembelajaran yang dilaksanakan harus mengacu kepada pola pembelajaran yang terpola dan berpedoman kepada 'kurikulum'; melengkapi madrasah diniyah dengan media pendidikan yang sesuai; dan dilaksanakannya wajib belajar diniyah oleh Pemerintah Daerah.

\section{Kesimpulan}

Madrasah diniyah merupakan lembaga pendidikan keagamaan Islam yang diselenggarakan menurut jaluar dan jenjang tertentu dengan tujuan untuk memberikan dasar dan/atau pendalaman tentang ilmu agama Islam. Madrasah diniyah memiliki landasan ideologis filosofis yang berdasarkan al-Qur'an dan Hadits Nabi Muhammad Saw. Madrasah diniyah di Indonesia memiliki sejarah panjang sejalan dengan sejarah pertumbuhan dan perkembangan Islam dan masyarakat muslim di Indonesia. Secara politik madrasah diniyah memiliki posisi strategis yang ditunjukkan dengan adanya kebijakan pemerintah maupun pemerintah daerah dalam menjaga eksistensi maupun mengembangkan madrasah diniyah untuk memenuhi kebutuhan masyarakat, bangsa dan negara. di antara kebijakan pemerintah

\footnotetext{
72 Zulfia Hanum Alfi Syahr, "Membentuk Madrasah Diniyah Sebagai Alternatif Lembaga Pendidikan elit Muslim Bagi Masyarakat", Intizar, Vol. 22 Nomor 2 (2016), 393-414.

73 Ibid.,26.
} 
daerah antara lain; memberikan bantuan dana untuk pengembangan madrasah diniyah, dan juga menerbitkan peraturan daerah dalam rangka mendorong perluasan akses masyarakat untuk mendapatkan pendidikan keagamaan Islam di madrasah diniyah. Di sisi manajemen, madrasah diniyah pada umumnya diselenggarakan tidak mengacu pada sisitem manajemen modern, hal ini disesbabkan oleh keterbatasan sumber daya yang dimiliki, namun demikian terdapat pula madrasah diniyah yang mampu menerapkan manajemen profesional. Meskipun pembelajaran di madrasah diniyah dilaksanakan dengan sistem klasikal, namun masih belum mampu menerapkan model pembelajaran modern yang menerapkan perkembangan teknologi masa kini, sehingga metode pembelajarannya masih lebih banyak pada metode tradisional dan monometode. Hal ini tidak terlepas dari keterbatasan sumber daya yang dimiliki oleh madrasah diniyah.

\section{Daftar Pustaka}

Abasri, "Sejarah dan Dinamika Lembaga-Lembaga Pendidikan Islam di Nusantara: Surau, Meunasah, Pesantren dan Madrasah", dalam Sejarah Pendidikan Islam, ed. Samsul Nizar (Jakarta: Kencana, 2008).

Alia, Nur, "Madrasah Diniyah Takmiliyah dalam Perspektif Standar

Pelayanan Minimal di Kabupaten Bogor", Penamas: Jurnal Penelitian Keagamaan dan Kemasyarakatan, Vol. 29 Nomor 3 (Oktober-Desember 2016).

Amin, Headri, Peningkatan Mutu Terpadu Pesantren dan Madrasah Diniyah (Jakarta: Diva Pustaka, 2004).

Asrohah, Hanun, Sejarah Pendidikan Islam (Jakarta: Logos Wacana Ilmu, 1999).

Atiqullah, "Strategi Pembelajaran Keagamaan Model Tematik di

Madrasah Diniyah Takmiliyah An-Nidzamia Palengaan

Pamekasan", Nuansa, Vo. 9 Nomor 2 (Juli Desember 2012).

Badrudin, "Indonesia's Educational Policies on Madrasah Diniyah

(MD)", Jurnal Pendidikan Islam, Vol. 3 Nomor 1 (2017).

Bakar, Isti'anah Abu, "Kelembagaan Madrasah di Indonesia", Madrasah, Vol. 3 No. 1 (Juli-Desember, 2010).

Bayhāqi, Abu Bakar Ah\}mad bin al-H\}usayn al-, Shu'b al-Imān Juz II

(Beyrut: Dar al-Kutub al-Alamiyah, $1410 \mathrm{H}$ ).

Bukhārī, Abū 'Abdillah Muhammad bin Ismāil al-, Matn al-Bukhārī Juz I (Indonesia: al-Haramayn, tt). 
Daulay, Haidar Putra, Sejarah Pertumbuhan dan Pembaruan Pendidikan Islam di Indonesia (Jakarta: Kencana, 2009).

Djumhur, I. dan H. Danasuparta, Sejarah Pendidikan (Bandung: CV. Ilmu, $\mathrm{tt}$ ).

Depertemen Agama RI, Pedoman penyelenggaraan dan Pembinaan Madrasah Diniyah (Jakarta: Depag, 2000).

Departemen Agama RI, Al-Qur'an dan Terjemahnya (Surabaya: AlHidayah, 2002).

Dhofier, Zamakhsyari, Tradisi Pesantren: Studi Pandangan Hidup Kyai dan Visinya Mengenai Masa Depan Indonesia (Jakarta: LP3Es, 2011).

Fathor Rachman dan Ach. Maimun, "Madrasah Diniyah Takmiliyah (MDT) Sebagai Pusat Pegetahuan Agama Masyarakat Pedesaan (Studi Peran MDT di Desa Gapura Timur Gapura Sumenep)", Anil Islam, Vol 9. Nomor 1 Juni (2016).

Fathurrahman, M., "Efektifitas Implementasi Kebijakan Program Wajib Belajar Madrasah Diniyah Awaliyah di Kabupaten

Pandeglang", Tanzhim: Jurnal Penelitian Manajemen

Pendidikan, Vol. 1 Nomor 1 (2016).

Fauzan, Indra dan Zakaria Taher, "Dinamika Pembuatan Peraturan Daerah Wajib Belajar Madrasah Diniyah Takmiliyah Awwaliyah di Kota Medan", Jurnal Ilmiah Mimbar Demokrasi, Vol. 16 Nomor 1 (Oktober 2016).

Fauzi, Anis dan Cecep Nikmatullah, "Pelaksanaan Pendidikan

Madrasah Diniyah di Kota Serang", Jurnal Pendidikan dan

Kebudayaan, Vol. 1 Nomor 2 (Agustus 2016).

https://kbbi.web.id/perspektif

Kementerian Agama RI, Pedoman Penyelenggaraan Madrasah

Diniyah Takmiliyah (Surabaya: Kanwil Kemenag Jawa Timur, 2015).

Kementerian Agama RI, Pedoman Penyelenggaraan Madrasah Diniyah (Surabaya: Kanwil Kementerian Agama Provinsi Jawa Timur, 2015).

Kementerian Agama RI, Panduan Model Pembelajaran Efektif Madrasah Diniyah Takmiliyah (Surabaya: Kanwil Kemenag Jawa Timur, 2015).

Maksum, Madrasah: Sejarah dan Perkembangannya (Jakarta: Logos Wacana Ilmu, 1999).

Mansur dan Mahfud Junaidi, Rekonstruksi Sejarah Pendidikan Islam (Jakarta: Departemen Agama RI, 2005).

Muslim, Muslim bin Hujjāj bin, S\}ahih Muslim Juz 2 (Surabaya: alHidayah, $\mathrm{tt}$ ). 
Nawāwī, Abī Abd al-Mu'tī Muhammad bin Umar bin Ali , Nihayat alZayn fi Irsyäd al-Mubtadiīn (Surabaya: al-Hidayah, $\mathrm{tt}$ ).

Nasir, M. Ridlwan, Mencari Tipologi Format Pendidikan Ideal Pondol Pesantren di Tengah Arus Perubahan (Yogyakarta: Pustaka Pelajar, 2010).

Nizah, Nuriyatun, "Dinamika Madrasah Diniyah: Suatu Tinjauan Historis", Edukasi: Jurnal Penelitian Pendidikan Islam, Vol. 11 Nomor 1 (Februari 2016).

Peraturan Menteri Agama No. 13 Tahun 2014 tentang Pendidikan Keagamaan Islam.

Peraturan Presiden RI No 87 Tahun 2017 tentang Pennguatan Pendidikan Karakter.

Qomar, Mujamil, Pesantren: Dari Transformasi Metodologi Menuju Demokratisasi Institusi (Jakarta: Erlangga, 2007).

Raharjo, Dawam, Intelektual Inteligensia dan Perilaku Politik Bangsa (Bandung: Mizan, 1993).

Ramayulis, Metodologi Pendidikan Agama Islam (Jakarta: Kalam Mulia, 2010).

Sharif, M.M., Alam Fikiran Islam. Penerj. Prof. Dr. Fuad Moh. Fachruddin (Bandung: CV. Diponegoro, 1979).

Steenbrink, Karel A., Pesantren, Madrasah, Sekolah: Pendidikan Islam dalam Kurun Moderen (Jakarta: LP3ES, 1994).

Syahri, Ahmad, "Penerapan Madrasah Unggulan di Madrasah Miftahul Huda Sumurpangganng Margadana Tegal Jawa Tengah", Al-Wijdan: Journal of Islamic Education Studies, Vol. 1 Nomor 1 (November 2016).

Syahr, Zulfia Hanum Alfi, "Membentuk Madrasah Diniyah Sebagai

Alternatif Lembaga Pendidikan elit Muslim Bagi Masyarakat", Intizar, Vol. 22 Nomor 2 (2016).

Wardi, Moh. "Problematika Pendidikan Islam Dan Solusi Alternatifnya (Perspektif Ontologis, Epistemologis dan Aksiologis)" Tadris Jurnal Pendidikan Islam STAIN Pamekasan, Volume 8 Nomor 1 Juni 2013.

www.akhmadsudrajat.wordpress.com.

Zuhairini dkk., Sejarah Pendidikan Islam (Jakarta: Bumi Aksara, 1985) 